\title{
Persepsi Konsumen Terhadap Pembelian Pangan Lokal Kupu (Studi Kasus Pada Industri Rumah Tangga Griya Jawau Melin Kelurahan Bukit Tunggal Kecamatan Jekan Raya Kota Palangka Raya)
}

\author{
Dina Graselita Putri, Emmy Uthanya Antang, Tri Yuliana Eka Sinta \\ Jurusan Sosial Ekonomi Pertanian, Universitas Palangka Raya \\ Email: emmyantang@ag.upr.ac.id
}

\begin{abstract}
This study aims to: (1) to know the consumer's characteristics of local food kupu (made of cassava), and (2) to know consumer perceptions of local food kupu. This research was a case study at the Home Industry "Griya Jawau Melin". The number of samples was 35 respondents, which has been specified with a convenience sampling technique. The research was designed both qualitative and quantitative methods, Data were collected through interviews with a questionnaire guide, and data were analyzed descriptively and using a Likert Scale. These results indicate that kupu consumers have varied characteristics, including gender, age, ethnic, education, occupation, and income. Consumers' perceptions of local food kupu which consist of variables i.e. taste, quality, price, sosial, and culture, are considered good with a score of 3203 and an average score of 79.58. The variable that gives the highest score was a culture with an average score of 84.57 , followed by sosial variables (average score 81.94), quality variable (average score 81.55), price variable (average score 77, 90), and lastly, the taste score with an average of 69.43. These results indicate that the most influencing purchases are cultural and sosial faktors, the taste faktor being the last variable influencing the purchase of Kupu after the quality and price variables.
\end{abstract}

Key words : Perception, Local food, Kupu

\section{Pendahuluan}

Diversifikasi pangan lokal menjadi salah satu strategi ketahanan pangan yang saat ini digaungkan oleh Kementerian Pertanian. Difokuskannya diversifikasi pangan pada pangan lokal sumber karbohidrat non beras yaitu: a). Untuk mengurangi ketergantungan terhadap beras; b). Menjamin ketersediaan pangan bagi masyarakat secara mandiri; c). Menjamin kecukupan gizi sehingga dapat hidup sehat, aktif, dan produktif. Selanjutnya, pengembangan produk pangan lokal menjadi strategi dalam menghadapi gempuran berbagai produk pangan yang banyak beredar di pasaran saat ini, khususnya yang berbahan baku tepung impor. Hal ini penting mengingat ketergantungan masyarakat Indonesia terhadap produk pangan berbahan baku tepung impor terus meningkat dari tahun ke tahun yang mengakibatkan tersedotnya devisa negara. Oleh karena itu, dibutuhkan inovasi dan kreativitas pelaku Usaha Mikro Kecil Menengah (UMKM) dalam pengembangan pangan lokal (Badan Ketahanan Pangan, 2020).

Salah satu alternatif pangan lokal yang banyak dikembangkan adalah ubi kayu. Ubi kayu atau singkong merupakan salah satu tanaman tropis yang paling berguna dan dimanfaatkan sebagai sumber kalori yang murah. Singkong merupakan tanaman yang memiliki kandungan gizi yang cukup lengkap. Kandungan zat dalam singkong ialah karbohidrat, fosfor, kalsium, vitamin C, protein, zat besi dan vitamin B1. Pemanfaatan tanaman singkong berkembang sebagai bahan baku industri pangan yang memiliki keunggulan berdasarkan aspek ketersediaan dan nutrisi. Keunggulan ini dapat menjadi faktor pendorong program diversifikasi pangan sebagai sumber kalori alternatif utama.

Potensi pengembangan pangan lokal oleh petani di Kalimantan Tengah adalah berbahan dasar ubi kayu. Salah satu olahan pangan lokal ubi kayu yang secara tradisional dikembangkan masyarakat Dayak adalah Кири. Кири merupakan produk olahan yang berbentuk seperti butiran beras namun terbuat dari bahan pangan non beras. Salah satu industri rumah tangga yang mengembangkan pangan lokal kupu adalah industri rumah tangga Griya Jawau Melin yang berada di Kelurahan Bukit Tunggal, Kecamatan Jekan Raya, Kota Palangka Raya. 
Untuk menghasilkan Kupu yang sesuai dengan harapan konsumen, produsen perlu memperbaiki atribut yang belum maksimal kinerjanya, sehingga konsumen tidak beralih ke produk pesaing. Konsumen dijadikan sebagai titik sentral perhatian dalam proses pemasaran. Mempelajari apa yang dibutuhkan dan diinginkan konsumen akan menuntun pada kebijakan pemasaran yang tepat dan efisien. Studi konsumen memberikan petunjuk untuk memperbaiki dan memperkenalkan produk atau jasa, menetapkan harga, perencanaan saluran, menyusun pesan, dan mengembangkan kegiatan pemasaran lain. Dalam model perilaku konsumen, proses dimulai dari stimuli pemasaran dan stimuli lainnya dari luar seperti ekonomi, teknologi, budaya, dan politik. Serangkaian stimuli tersebut akan dipengaruhi dan mempengaruhi psikologi dan karakteristik konsumen, yang selanjutnya berlanjut pada proses keputusan pembelian.

Persepsi konsumen adalah tanggapan konsumen terhadap keberadaan suatu obyek atau produk yang menjadi pilihannya. Menurut Kotler dan Amstrong (2013), bahwa dalam keadaan yang sama, persepsi seseorang terhadap suatu produk dapat berbeda-beda. Hal ini dikarenakan oleh adanya proses seleksi terhadap berbagai stimulus yang ada. Pada hakekatnya persepsi akan berhubungan dengan perilaku seseorang dalam mengambil keputusan terhadap apa yang dikehendaki. Dengan persepsi konsumen, dapat mengetahui hal-hal apa saja yang menjadi kekuatan, kelemahan, kesempatan ataupun ancaman bagi produk yang ditawarkan kepada konsumen, sehingga akan menjadi acuan selanjutnya bagi pelaku usaha untuk mengembangkan produknya. Berdasarkan latar belakang tersebut, penelitian ini bertujuan untuk Mengetahui karakteristik konsumen pangan lokal kupu.dan Mengetahui persepsi konsumen terhadap pangan lokal kupu.

\section{Metode Penelitian}

Penelitian ini merupakan studi kasus yang dilaksanakan pada Industri Rumah Tangga Griya Jawau Melin. Pemilihan lokasi dilakukan secara sengaja dengan pertimbangan bahwa industri rumah tangga tersebut merupakan satu-satunya industri yang mengolah pangan lokal kupu dalam kemasan yang memiliki izin usaha yang didapat dari Dinas Koperasi dan Usaha Kecil Menengah dan mendapat perizinan Produksi Pangan Industri Rumah Tangga (PIRT) dari Dinas Kesehatan. Dilaksanakan selama 3 (tiga) bulan sejak bulan Oktober sampai Desember 2020.

Metode pengambilan sampel yang digunakan adalah teknik non probability sampling dengan teknik convinience sampling. Jumlah sampel yang diambil adalah sebanyak 35 orang, adalah pengunjung yang bersedia menjadi sampel penelitian. Kriteria sampel yang diajukan dalam penelitian ini adalah : a) Mengetahui tentang pangan lokal kupu; dan b) Pria atau wanita yang merupakan konsumen Industri Griya Jawau Melin membeli secara langsung kupu ke industri rumah tangga Griya Jawau Melin.

Data yang digunakan dalam penelitian ini yakni data primer dan data sekunder. Data primer meliputi karakteristik responden, persepsi konsumen, dan keputusan pembelian konsumen yang diperoleh dari lokasi penelitian melalui observasi dan wawancara langsung kepada responden dengan menggunakan kuesioner.

Data karakteristik konsumen dianalisis dengan menggunakan analisis deskriftif, dan persepsi konsumen terhadap terhadap Кири dianalisis dengan menggunakan Skala Likert. Variabel dan indikator yang digunakan seperti pada Tabel 1.

Tabel 1. Variabel dan Indikator Pengukuran Persepsi Konsumen

\begin{tabular}{ll}
\hline Variabel & Indikator \\
\hline Cita Rasa & 1. Rasa \\
& 2. Aroma \\
& 3. Tekstur \\
\hline Kualitas & 1. Kemasan \\
& 2. Waktu simpan \\
& 3. Substitusi pangan \\
& 4. Cara pengolahan \\
\hline
\end{tabular}




\begin{tabular}{ll}
\hline Harga & 1. Keterjangkauan harga \\
& 2. Kesesuaian harga \\
\hline Sosial & 1. Kelompok referensi \\
& 2. Keluarga \\
\hline Budaya & $\begin{array}{l}\text { 1. Kebiasaan makan } \\
\text { 2. Daerah asal } \\
\end{array}$ \\
3. Etnis \\
\hline
\end{tabular}

Sejumlah 5 variabel dengan 15 jumlah indikator dan 23 item pernyataanmemberikan skor minimum sebesar 805 dan skor maksimum sebesar 4025 dengan interval kelas yaitu 644. Sehingga pembagian masing-masing kategori dijelaskan sebagai berikut:

1. $805-1449=$ persepsi tergolong kategori sangat tidak baik

2. $1450-2093=$ persepsi tergolong kategori tidak baik

3. $2094-2737=$ persepsi tergolong kategori netral

4. $2738-3381=$ persepsi tergolong kategori baik

5. $3382-4025=$ persepsi tergolong kategori sangat baik

\section{Hasil dan Pembahasan}

Responden terdiri dari laki-laki dan perempuan, dengan komposisi perempuan $(74,3 \%)$ lebih banyak daripada laki-laki $(25,7 \%)$, rentang usia yang sangat lebar berkisar antara $23-73$ tahun dengan rata-rata usia 52,6 tahun. Responden berasal berbagai suku, yaitu: Dayak (65,7 \%), Banjar $(14,3 \%)$, dan Jawa (20,0 \%). Walaupun Kupu merupakan pangan lokal suku dayak, namun dari suku lainpun menyukainya karena ada kemiripan dengan pangan lokal yang ada di daerahnya. Rentang Pendidikan dari SMP sampai dengan Perguruan Tinggi dengan jumlah responden terbanyak berpendidikan SMA $(54,3 \%)$.

Tabel 2. Karakteristik Responden Konsumen Kupu di Industri Rumah Tangga Griya Jawau Melin

\begin{tabular}{|c|c|c|c|}
\hline No & Jenis Karakteristik & Jumlah & $\%$ \\
\hline \multirow[t]{3}{*}{1.} & Jenis Kelamin (orang) & & \\
\hline & a. Laki- laki & 9 & 25,7 \\
\hline & b. Perempuan & 26 & 74,3 \\
\hline \multirow[t]{4}{*}{2.} & Usia (Tahun) & & \\
\hline & a. Usia termuda & 23 & - \\
\hline & b. Usia tertua & 73 & - \\
\hline & c. Rata-rata & 52,6 & - \\
\hline \multirow[t]{4}{*}{3.} & Suku (orang) & & \\
\hline & a. Dayak & 23 & 65,7 \\
\hline & b. Banjar & 5 & 14,3 \\
\hline & c. Jawa & 7 & 20,0 \\
\hline \multirow[t]{4}{*}{4.} & Pendidikan (orang) & & \\
\hline & b. SMP & 6 & 17,1 \\
\hline & c. SMA & 19 & 54.3 \\
\hline & e. S1 & 10 & 28,6 \\
\hline \multirow[t]{5}{*}{5 . } & Pekerjaan (orang) & & \\
\hline & a. Pegawai Negeri Sipil (PNS) & 5 & 14,3 \\
\hline & b. Swasta & 17 & 48,6 \\
\hline & c. Ibu Rumah Tangga & 7 & 20,0 \\
\hline & d. Pensiunan PNS & 6 & 17,1 \\
\hline \multirow[t]{2}{*}{6.} & Pendapatan (orang) & & \\
\hline & a. $<1.500 .000$ & 7 & 20,0 \\
\hline
\end{tabular}




$\begin{array}{lrl}\text { b. } 1.500 .000-2.499 .000 & 18 & 51,4 \\ \text { c. } 2.500 .000-3.500 .000 & 4 & 11,4 \\ \text { d. }>3.500 .000 & 6 & 17,1\end{array}$

Sumber: Data Primer diolah, 2021

Pekerjaan responden terbanyak adalah swasta $(48,6 \%)$, diikuti oleh ibu rumahtangga $(20,0 \%)$. Pensiunan PNS (17,1 \%), dan Pegawai Negeri Sipil (14,3\%). Dengan pendapatan rata-rata sebesar Rp. 2.122.428,57 pada rentang pendapatan antara Rp. 500.000,00 - Rp. 5.000.000,00. Berdasarkan kategori yang ditetapkan oleh Badan Pusat Statitik pendapata konsumen berada pada kategori sedang.

Persepsi konsumen merupakan suatu proses yang dilalui seseorang dalam melakukan pilihan, penyusunan, dan penafsiran informasi guna mendapatkan artiatau keputusan. Nilai persepsi konsumen yang diwakili oleh beberapa responden berdasarkan hasil total skor masing-masing variabel persepsi terdiri dari persepsi terhadap cita rasa, kualitas, harga, sosial, dan budaya. Dalam penelituan ini persepsi konsumen dikelompokkan dalam kategori sangat baik, baik, netral, kurang baik, sangat tidak baik.

Cita rasa adalah penilaian terhadap sensasi kompleks yang diperoleh selama individu melakukan pengecapan dan berkaitan erat dengan penerimaan individu terhadap bahan pangan. Jadi dapat disimpulkan bahwa selama individu melakukan pengecapan, individu akan mempersepsi sensasi kompleks yang disebut citarasa. Cita rasa mencakup banyak faktor, seperti substansi, aroma, tekstur, suhu, warna, dan suara yang ditimbulkan pada saat substansi dikunyah (Schiffman, 1990). Persepsi cita rasa merupakan hasil interaksi antara aspek: rasa, bau atau aroma, iritasi akibat persinggungan dengan bahan kimia, suhu, warna, tekstur dan bunyi yang dihasilkan saat makanan dikunyah. karena persepsi citarasa berkaitan erat dengan penerimaan terhadap bahan pangan. Tingkat persepsi konsumen terhadap pangan lokal kupu pada variabel cita rasa ditunjukkan pada Tabel 3.

Tabel 3. Rekapitulasi Persepsi Konsumen Terhadap Pangan Lokal Kupu pada Variabel Cita Rasa

\begin{tabular}{lccccc}
\hline \multicolumn{1}{c}{ Variabel } & Indikator & Item & Skor & Rata-rata & Kategori \\
\hline Cita Rasa & Rasa & 2 & 251 & 71,71 & Baik \\
& Aroma & 1 & 116 & 66.29 & Netral \\
& Tekstur & 1 & 119 & 68,00 & Netral \\
\hline Total & & 4 & 486 & 69.43 & Baik \\
\hline
\end{tabular}

Sumber: Data Primer diolah, 2021

Berdasarkan Tabel 3 dapat dilihat bahwa persepsi konsumen terhadap pangan lokal kupu pada variabel cita rasa dengan 3 indikator mendapat nilai skor 486 dengan rata- rata 69,43\% yang termasuk dalam kategori baik. Pada indikator rasa dengan nilai $71,71 \%$ yang mana termasuk dalam kategori baik. Tingginya nilai skor dan nilai rata-rata pada indikator rasa dikarenakan konsumen menyatakan кири mempunyai rasa yang enak dan cocok dengan selera konsumen. Dalam proses pengolahannya kupu dicampur garam dan parutan kelapa untuk menambah rasa. Selanjutnya indikator tekstur dengan nilai rata-rata 68,00 \% termasuk kategori netral. Sebagian konsumen menyatakan bahwa tekstur кири mirip seperti nasi dan cocok untuk dimakan bersama lauk pauk. Kemudian indikator aroma dengan skor 116 dengan nilai rata- rata 66,29\% termasuk kategori netral hal tersebut dikarenakan кири mempunyai aroma yang khas yang tidak semua konsumen bisa menerimanya. Adanya aroma pada kupu biasanya dipengaruhi dalam proses pembuatannya. Apabila kupu dalam proses pembuatannya bersih maka aroma yang ditimbulkan akan berkurang.

Persepsi kualitas (perceived quality) dapat didefinisikan sebagai persepsi konsumen terhadap keseluruhan kualitas atau keunggulan suatu produk atau jasa layanan berkaitan dengan apa yang diharapkan oleh konsumen. Persepsi kualitas yang dirasakan oleh konsumen berpengaruh terhadap kesediaan konsumen tersebut untuk membeli sebuah produk. Ini berarti bahwa semakin tinggi nilai yang dirasakan oleh konsumen, maka akan semakin tinggi pula kesediaan konsumen tersebut untuk akhirnya membeli. Kualitas produk menurur Kotler dan Amstrong (2010) adalah kemampuan suatu produk untuk melaksanakan fungsinya, meliputi daya tahan, keandalan, ketepatan, kemudahan operasi 
dan perbaikan, serta atribut bernilai lainnya. Seorang konsumen melakukan pembelian suatu produk tidak hanya berdasar pada bentuk fisik dari suatu produk, tetapi daya guna dan keandalan yang ada pada suatu produk tersebut apakah memiliki fungsi dan manfaat yang sesuai dengan kebutuhan konsumen tersebut atau tidak. Tingkat persepsi konsumen terhadap pangan lokal kupu pada variabel cita rasa ditunjukkan pada Tabel 4.

Tabel 4. Rekapitulasi Persepsi Konsumen Terhadap Pangan Lokal Kupu pada Variabel Kualitas

\begin{tabular}{cccccc}
\hline Variabel & Indikator & Item & Skor & Rata-rata & Kategori \\
\hline Kualitas & Kemasan & 3 & 453 & 86,29 & Sangat Baik \\
& Waktu Simpan & 1 & 170 & 97,14 & Sangat Baik \\
& Substitusi Pangan & 2 & 241 & 68,86 & Baik \\
& Cara Pengolahan & 1 & 135 & 77,14 & Baik \\
\hline Total & & 7 & 999 & 81,55 & Baik \\
\hline
\end{tabular}

Sumber: Data Primer diolah, 2021

Berdasarkan Tabel 4 dapat dilihat bahwa persepsi konsumen terhadap pangan lokal kupu pada variabel kualitas dengan 4 indikator mendapat nilai skor 486 dengan nilai rata- rata 81,55\% yang termasuk dalam kategori baik. Pada indikator kemasan dengan nilai rata-rata 86,29\% dengan nilai skor 453 termasuk dalam kategori sangat baik. Kemasan memiliki pengaruh penting terhadap penjualan dan daya saing di pasaran. Sebuah kemasan produk yang unik dan menarik cenderung memberikan kesan positif terhadap merek dan kualitas barang. Konsumen menilai sebuah barang melalui kemasan yang ditampilkan. Konsumen menyatakan kemasan kupu yang dijual memiliki ketebalan yang cukup baik serta pada kemasan tertera masa kadaluwarsa/expired date yang meyakinkan konsumen untuk membeli kupu. Selanjutnya indikator waktu simpan dengan nilai ratarata $97,14 \%$ termasuk dalam kategori sangat baik. Hal tersebut dikarenakan kupu yang dijual dibuat kering membuat umur simpan kupu dapat bertahan lama sampai 6 bulan lamanya sehingga konsumen tidak perlu khawatir apabila kupu mengalami kerusakan dan kadaluwarsa. Kemudian indikator cara pengolahan dengan nilai rata-rata 77,14 \% dengan nilai skor 135 termasuk dalam kategori sangat baik cara mengolah sangat perlu diketahui apalagi untuk orang yang baru pertama kali mencoba kupu. Dengan adanya informasi cara pengolahan akan memudahkan konsumen dalam memasak kupu. Indikator substitusi pangan dengan nilai rata rata 68,86\% dengan skor 241 termasuk kategori baik, karena kuри yang merupakan makanan tradisional seiring dengan perkembangan jaman, pengaruh globalisasi, dan perubahan gaya hidup masyarakat modern mulai ditinggalkan karena dianggap kurang menarik. Oleh karena itu hanya beberapa konsumen yang memilih untuk tetap mengosumsi dan sebagian besar hanya sesekali mengosumsi kupu.

Menurut Schiffman dan Kanuk (2008) persepsi harga adalah pandangan atau persepsi mengenai harga bagaimana konsumen memandang harga tertentu (tinggi, rendah, wajar) memberikan pengaruh yang kuat terhadap keinginan dan kepuasan membeli. Persepsi harga (price perception) adalah nilai yang terkandung dalam suatu harga yang berhubungan dengan manfaat dan memiliki atau menggunakan suatu produk atau jasa (Kotler dan Amstrong 2008). Peter dan Olson (2010) menjelaskan bahwa persepsi harga berkaitan dengan bagaimana informasi harga dipahami seluruhnya oleh konsumen dan memberikan makna yang dalam. Pada saat konsumen melakukan evaluasi dan penelitian terhadap harga dari suatu produk sangat dipengaruhi oleh perilaku konsumen. Dapat disimpulkan persepsi harga adalah suatu pemikiran/penafsiran konsumen terhadap jumlah uang yang akan digunakan untuk mendapatkan suatu produk atau jasa yang diinginkan dengan nilai pengorbanan yang sesuai dengan apa yang didapatkan dari produk atau jasa.

Tabel 5. Rekapitulasi Persepsi Konsumen Terhadap Pangan Lokal Kupu pada Variabel Harga

\begin{tabular}{cccccc}
\hline Variabel & Indikator & Item & Skor & Rata-rata & Kategori \\
\hline \multirow{2}{*}{ Harga } & Keterjangkauan Harga & 1 & 133 & 76,00 & Baik \\
& Kesesuaian Harga & 2 & 276 & 78,86 & Baik \\
\hline Total & & & 409 & 77,90 & Baik \\
\hline
\end{tabular}

Sumber: Data Primer diolah, 2021 
Berdasarkan Tabel 5 dapat dilihat bahwa persepsi konsumen terhadap pangan lokal kupu pada variabel harga dengan 2 indikator mendapat nilai skor 409 dengan nilai rata- rata 77,90\% yang termasuk dalam kategori baik. Pada indikator kesesuaian harga dengan nilai rata-rata 78,86\% termasuk dalam kategori baik. Hal ini dikarenakan konsumen setuju dengan harga yang ditawarkan dan sesuai dengan kualitas yang didapat. Konsumen menyatakan bahwa kupu yang dibeli sesuai dengan harapan yaitu bersih dan tidak berbau. Selanjutnya pada indikator keterjangkaun harga dengan nilai rata-rata $76,00 \%$ termasuk dalam kategori baik hal ini dikarenakan konsumen setuju bahwa harga kupu yang dijual sebesar Rp. 15.000 dengan berat perbungkus 500 gram terjangkau mengingat kupu susah ditemui dan jarang dijual.

Selanjutnya, sosial adalah semua interaksi sosial antara masyarakat, baik secara langsung, misalnya dengan berdiskusi dengan seorang teman, maupun secara vicarious, yaitu pengamatan mengenai apa yang sedang dilakukan atau dikenakan orang lain (Peter dan Olson, 2000). Seseorang belajar sesuatu melalui dua jenis interaksi tersebut Bintarto dan Surastopo mendefinisikan lingkungan sosial sebagai lingkungan tempat individu berinteraksi, yang memiliki beberapa aspek yaitu sikap kemasyarakatan, sikap kejiwaan, sikap kerohanian, dan lain sebagainya. Lingkungan sosial dibedakan menjadi dua, yaitu lingkungan sosial makro dan lingkungan sosial mikro. Lingkungan mikro adalah lingkungan yang sangat dekat dengan konsumen, yang berinteraksi langsung dengan konsumen. Sedangkan lingkungan makro adalah lingkungan yang jauh dari konsumen (Peter dan Olson, 2000).

Tabel 6. Rekapitulasi Persepsi Konsumen Terhadap Pangan Lokal Kupu pada Variabel Sosial

\begin{tabular}{cccccc}
\hline Variabel & Indikator & Item & Skor & Rata-rata & Kategori \\
\hline Sosial & Kelompok Referensi & 3 & 391 & 74,48 & Baik \\
& Keluarga & 2 & 326 & 93,14 & Sangat Baik \\
\hline & & 5 & 965 & 78,78 & Baik \\
\hline
\end{tabular}

Sumber : Data Primer diolah, 2021

Berdasarkan Tabel 6 persepsi konsumen terhadap pangan lokal kupu pada variabel harga dengan 2 indikator mendapat nilai skor 409 dengan nilai rata- rata 78,78\% yang termasuk dalam kategori Baik. Pada indikator keluarga dengan nilai rata-rata 93,14 \% termasuk dalam kategori sangat baik. Hal ini dikarenakan adamya pengaruh oleh keluarga dalam kebiasaan makan dan pengambilan keputusan pangan yang dikonsumsi, sebagian besar konsumen menyatakan sudah terbiasa mengonsumsi kupu sejak kecil atau dengan kata lain bukan baru pertama kali mencoba. Selanjutnya indikator kelompok referensi dengan nilai rata-rata 74,48 \% termasuk kategori baik hal ini dikarenakan informasi dan saran yang diberikan kelompok acuan dalam penelitian ini secara langsung tidak mempengaruhi konsumen untuk memutuskan melakukan pembelian. Konsumen membutuhkan lebih dari sekedar informasi dan saran yang dapat dipercaya untuk memutuskan melakukan pembelian. Konsumen memperhatikan sikap yang ditunjukkan orang lain, serta berubahnya minat pembelian yang dimiliki konsumen karena suatu faktor yang tidak diantisipasi sebelumnya.

Budaya telah menjadi konsep penting dalam memahami masyarakat dan kelompok manusia untuk waktu yang lama. Budaya dapat diartikan sebagai gabungan kompleks asumsi tingkah laku, cerita, mitos, metafora dan berbagai ide lain yang menjadi satu untuk menentukan arti menjadi anggota masyarakat tertentu tentang pengertian yang salah atau sebagai sesuatu yang benar menurut budaya yang diyakini. Budaya adalah sebagai suatu pola semua susunan baik material maupun perilaku yang sudah diadposi masyarakat sebagai suatu cara tradisional dalam memecahkan masalahmasalah para anggotanya (Moeljono, 2003). Budaya memiliki pengaruh besar pada cara pandang dan persepsi seseorang pada hal-hal yang dia lihat, rasakan dan alami. Nilai-nilai moral dan etiket suatu masyarakat bervariasi, bergantung pada budaya yang memberikan masyarakat tersebut suatu pengertian yang diterima secara luas dan mutlak dikelompoknya.

Tabel 7. Rekapitulasi Persepsi Konsumen Terhadap Pangan Lokal Kupu pada Variabel Budaya

\begin{tabular}{cccccc}
\hline Variabel & Indikator & Item & Skor & Rata-rata & Kategori \\
\hline Budaya & Kebiasaan makan & 281 & 2 & 80,92 & Baik \\
& Daerah Asal & 141 & 1 & 80,87 & Baik
\end{tabular}




\begin{tabular}{|c|c|c|c|c|c|}
\hline & Etnis & 170 & 1 & 97,14 & Sangat Baik \\
\hline Total & & 592 & 4 & 84,57 & Baik \\
\hline
\end{tabular}

Sumber: Data Primer diolah, 2021

Berdasarkan Tabel 7, persepsi konsumen terhadap pangan lokal kupu pada variabel budaya dengan 3 indikator mendapat nilai skor 592 dengan nilai rata- rata 84,57 \% yang termasuk dalam kategori baik. Indikator etnis memiliki nilai tertinggi rata-rata 97,14 termasuk dalam kategori sangat baik. Karena kири yang merupakan pangan lokal khas suku Dayak Kalimantan Tengah juga di beli dan dikonsumsi oleh konsumen dari suku lain selain suku Dayak. Setiap suku bangsa mengembangkan cara turun-temurun untuk mencari, memilih, menangani, menyiapkan dan menyajikan makanan. Namun Cita rasa dan cara penyajian yang hampir mirip dengan tiwul pangan lokal masyarakat suku Jawa membuat kupu dapat diterima dengan mudah oleh masyarakat Jawa dan suku lannya mengingat tiwul sudah lebih dulu dikenal luas dan diterima oleh masyarakat. Pada indikator kebiasaan makan dengan nilai rata-rata $80,92 \%$ termasuk kategori baik. Makanan mempunyai fungsi majemuk dalam masyarakat setiap bangsa. Fungsi tersebut bukan hanya sebagai fungsi biologis, tetapi juga fungsi sosial, budaya, dan agama. Makanan erat kaitannya dengan tradisi suatu masyarakat setempat, karena itu makanan memiliki fenomena lokal. Seluruh aspek makanan tersebut merupakan bagian-bagian dari warisan tradisi suatu golongan masyarakat. Makanan dapat digunakan sebagai aset atau modal bagi suatu bangsa untuk mempertahankan nilai kebiasaan dari suatu masyarakat yang dihasilkan oleh masyarakat itu sendiri (Ihroni, 2006). Kebiasaan makan adalah tingkah laku manusia atau kelompok manusia dalam memenuhi kebutuhannya akan makan yang meliputi sikap, kepercayaan atau pemilihan makanan. Kebiasaan makan sebagai cara-cara individu dan kelompok individu memilih, mengkonsumsi dan menggunakan makanan-makanan yang tersedia didasarkan kepada faktor-faktor sosial budaya dimana ia atau mereka hidup.

Selanjutnya indikator daerah asal dengan nilai rata-rata 80,87 termasuk kategori baik. Daerah asal adalah suatu tempat dimana penduduk itu dilahirkan atau tinggal semasa kecil atau remajanya. Daerah asal juga berarti kampung halaman. Sebagian besar konsumen menyatakan setuju bahwa daeah asal mempengaruhi dalam proses pembelian barang dan jasa termasuk pembelian pangan untuk dikonsumsi sehari-hari.

Berdasarkan analisis skor (skala likert) sebelumnya pada masing-masing varibabel yakni cita rasa, kualitas, harga, sosial, dan budaya. Selanjutnya dilakukan analisis secara keseluruhan yang mana hasil pada masing-masing variabel tersebut digabungkan dan dianalisis. Untuk mengetahui nilai skor dan tingkat persepsi konsumen terhadap pangan lokal kupu dapat dilihat pada Tabel 8 .

Tabel 8. Rekapitulasi Skor Persepsi Konsumen Terhadap Pangan Lokal Kupu pada Keseluruhan Variabel

\begin{tabular}{lcccc}
\hline Variabel & Item & Skor & Rata-rata & Kategori \\
\hline Cita Rasa & 4 & 486 & 69,43 & Baik \\
Kualitas & 7 & 999 & 81,55 & Baik \\
Harga & 3 & 409 & 77,90 & Baik \\
Sosial & 5 & 717 & 81,94 & Baik \\
Budaya & 4 & 592 & 84,57 & Baik \\
\hline Total & 23 & 3203 & 79,58 & Baik \\
\hline
\end{tabular}

Sumber: Data Primer diolah, 2021

Berdasarkan Tabel 8, persepsi konsumen terhadap pangan lokal kupu pada variabel keseluruhan variable menunjukkan kategori baik dengan skor rata-rata 79,58, variable yang memberikan skor tertinggi adalah budaya dengan skor rata-rata 84,57, diikuti variabel sosial (skor rata-rata 81,94), variable kualitas (skor rata-rata 81,55), variable harga (skor rata-rata 77,90), dan terakhir skor cita rsa dengan rata-rata 69,43. Hasil ini menunjukkan bahwa yang paling mempengaruhi pembelian adalah faktor budaya dan sosial, faktor cita rasa menjadi variable yang terakhir mempengaruhi pembelian kири setelah variable kualitas dan harga. 


\section{Kesimpulan}

1. Karakteristik konsumen kири di Industri Rumah Tangga Griya Jawau Melin menurut jenis kelamin terbanyak adalah perempuan sebanyak 26 orang dengan persentase sebesar $74,3 \%$, menurut usia termuda adalah 23 tahun dengan dan usia tertua 73 tahun dengan persentase sebesar 52,6\%, menurut suku terbanyak adalah suku Dayak sebanyak 23 orang dengan persentase 65,7\%, menurut pendidikan terakhir terbanyak yakni Sekolah Menengah Atas (SMA) sebanyak 19 orang dengan persentase $54,3 \%$, menurut pekerjaan terbanyak adalah swasta sebanyak 17 orang dengan persentase $48,6 \%$, menurut pendapatan terbanyak mempunyai pendapatan sedang dengan rata-rata pendapatan Rp. 1.500.000 - 2.500.000 sebanyak 18 orang dengan persentase 51,4\%.

2. Persepsi konsumen terhadap pangan lokal kupu pada variabel cita rasa mendapat nilai skor 486 dan nilai rata-rata sebesar 69,43 dengan indikator rasa termasuk dalam kategori baik, sedangkan indikator aroma dan tekstuk termasuk dalam kategori netral. Pada variabel kualitas mendapat nilai skor 999 dan nilai rata-rata sebesar 81,55 dengan indikator kemasan dan waktu simpan termasuk dalam kategori sangat baik sedangkan substitusi pangan dan cara pengolahan termasuk dalam kategori baik. Pada variabel harga mendapat nilai skor 409 dan nilai rata-rata sebesar 77,90 dengan indikator keterjangkauan harga dan kesesuaian harga termasuk dalam kategori baik. Pada variabel sosial mendapat nilai skor 717 dan nilai rata-rata sebesar 81,94 dengan indikator keluarga termasuk dalam sangat tinggi sedangkan indikator kelompok referensi termasuk kategori tinggi. Pada variabel budaya mendapat nilai skor 592 dan nilai rata-rata sebesar 84,57 sehingga apabila ditotal mendapat nilai skor 3203 dan nilai rata- rata 79,58 dengan indikator etnis termasuk dalam kategori sangat baik sedangkan kebiasaan makan daerah asal termasuk dalam kategori baik.

\section{Daftar Pustaka}

Assauri, S. 2004. Manajemen Produksi dan Operasi. Lembaga Penerbit Fakultas Ekonomi Universitas Indonesia.

Badan Ketahanan Pangan. 2020. Petunjuk Teknis Pengembangan Industri Pangan Lokal (PIPL) Berbasis UMKM Tahun 2020.

Davis. K. 1997. "Human Behavior at Work: Organizational Behavior (Perilaku Dalam Organisasi)”. Terjemahan: Agus Dharma. Erlangga: Jakarta.

Ernawati, S. 2017. Persepsi Konsumen Terhadap Beras Sehat Bogowonto. Skripsi. Program Studi Agribisnis. Fakultas Pertanian. Universitas Muhammadiyah Purworejo.

Garvin, D. A. \& Lovelock. 2004. Strategi Marketing. Penerbit Andi. Yogyakarta.

Gerson, R. F. 2004. Mengukur Kepuasan Pelanggan. Penerbit Andi: Yogyakarta.

Ghozali, I. 2009. Aplikasi Analisis Multivariate dengan Program SPSS. Penerbit Universitas Dipenogoro. Semarang.

Hanafie, R. 2010. Penyediaan Pangan Yang Aman Dan Berkelanjutan Guna Mendukung Tercapainya Ketahanan Pangan. JSEP (Journal of Sosial and Agricultural Economics).

Hariyadi, P. 2010. Mewujudkan Keamanan Pangan Produk-Produk Unggulan Daerah. Prosiding Seminar Nasional "Peran Keamanan Pangan Produk Unggulan Daerah dalam Menunjang Ketahanan Pangan dan Menekan Laju Inflasi"

Hassan, Z. H. 2013. Aneka Tepung Berbasis Bahan Baku Lokal Sebagai Sumber Pangan Fungsional Dalam Upaya Meningkatkan Nilai Tambah Produk Pangan Lokal. Balai Besar Penelitian dan Pengembangan Pascapanen Pertanian. Jurnal Pangan, Vol. 23 No. 1 Maret 2014 : 93 - 107. 
Peter, P. J. \& Olson, J. C. 2000. Perilaku Konsumen dan Strategi Pemasaran. Edisi keempat. Jilid 1. Erlangga. Jakarta.

Irawan, H. 2009. 10 Prinsip Kepuasan Pelanggan. Elex Media Komputindo. Jakarta.

Kotler, P. \& Keller, K. L. 2009. Manajemen Pemasaran. Jilid II. Edisi ke 13. Erlangga. Jakarta.

Kotler, P. \& Amstrong, G. 2013. Prinsip-prinsip Pemasaran, Edisi ke-12. Penerbit Erlangga. Jakarta.

Lamb, C. W., Hair, J. F. \& McDaniel, C. 2001. Pemasaran. Edisi Pertama. Salemba Empat. Jakarta.

Muctadi \& Sugiyono. 2016. Ilmu Pengetahuan Bahan Pangan. PAU IPB: Bogor.

Moeljono, D. 2003. Budaya Korporat dan Keunggulan Korporasi. PT. Elex Media Komputindo: Jakarta.

Pravita, D. I. A. R,. Sudarta, W. \& Ustriyana, I. N. G. 2013. Persepsi Konsumen Terhadap Beras Organik Dan Anorganik Di Toko Satvika Boga Sanur Denpasar. Jurnal Agribisnis Dan Agrowisata. Vol. 2, No. 2, April 2013.

Rachman, H. P. S. \& Suryani, E. 2008. Perubahan Pola Konsumsi Pangan Sumber Karbohidrat Di Perdesaan. Jurnal Pangan. Edisi No. 52/XVII/Oktober-Desember/2008.

Rachman, H. P. S,. Ariani, M,. Hardono, G. S. \& Purwantini, T. B. 2008. Analisis wilayah Rawan Pangan dan Gizi Kronis serta Alternatif Penanggulangannya. Pengembangan Inovasi Pertanian. 1(1), 66-73.

Robbins, S. P. 2003. Perilaku Organisasi. Index. Jakarta

Schiffman, L. G. \& Kanuk, L.L. 2004. Perilaku konsumen. Edisi 7. Indeks. Jakarta.

Setiadi J. N. 2003. Perilaku Konsumen: Perspektif Kontemporer pada Motif, Tujuan, dan Keinginan Konsumen. PT Kharisma Putra Utama. Jakarta.

Sitinjak, T.J. R \& Sugiarto. 2006. LISREL. Graha Ilmu. Yogyakarta.

Subekti,. Utomo, T.P,. Rayid, L. A,. Mukti. \& Muhartono. 2017. Analisis Preferensi Konsumen Terhadap Beras Siger Di Bandar Lampung. Jurusan Teknologi Hasil P6 ltas Pertanian Universitas Lampung.

Sugiyono. 2007. Penelitian Kuantitatif dan Kualitatif. R\&D. Alfabeta. Bandung.

Suhartini, M,. Khotimah, K. \& Hidayat, R. 2020. Persepsi Konsumen dan Pengambilan Keputusan Pembelian Terhadap Produk Sehat Di Asri Organik- Sehat Tambakrejo Jombang. Agrosaintifika: Jurnal Ilmu-Ilmu Pertanian.Volume 2 No 2, Mei 2020

Sumaryanto. 2009. Diversifikasi Sebagai Salah Satu Pilar Ketahanan Pangan. Pusat Analisis Sosial Ekonomi dan Kebijakan Pertanian. Jurnal Penelitian dan Pengembangan Pertanian.

Sunaryo. 2004. Psikologi Untuk Pendidikan. EGC. Jakarta.

Suryana, A. 2003. Kapita Selekta Evolusi Pemikiran Kebijakan Ketahanan Pangan. Fakultas Ekonomi. Universitas Gadjah Mada.

Susanti, A. 2019. Persepsi dan Proses Pengambilan Keputusan Konsumen Terhadap Produk Olahan Hasil Perikanan (Studi Kasus Ikm Bahek Ewaki Di Desa Kurau Barat Kecamatan Koba Kabupaten Bangka Tengah). Skripsi. Program Studi Agribisnis. Fakultas Pertanian dan Biologi. Universitas Bangka Belitung.

Tjiptono, F. 2010. Strategi Pemasaran Edisi 2. Andi Offset: Yogyakarta.

Umar, H. 2003. Metode Riset Perilaku Konsumen Jasa. Ghalia Indonesia: Jakarta.

Undang-Undang Republik Indonesia Nomor 18 Tahun 2012.Tentang Pangan. 
Undang- Undang Republik Indonesia. Nomor 8 Tahun 1999 Pasal 4. Tentang Perlindungan Konsumen.

Walgito, B. 2002. Pengantar Psikologi Umum. Andi Offset: Yogyakarta.

Waskito D,. Ananto, M. Z. \& Rezza, A. 2014. Persepsi Konsumen Terhadap Makanan Organik Di Yogyakarta. Jurnal Penelitian Mahasiswa Universitas Negeri Yogyakarta. Volume Ix, Nomor 1, April 2014. 